\title{
HMB-45-Positive Neoplastic Cells Present
}

National Cancer Institute

\section{Source}

National Cancer Institute. HMB-45-Positive Neoplastic Cells Present. NCI Thesaurus.

Code C43268.

An immunohistochemical finding that the monoclonal antibody HMB-45 binds to a sample of neoplastic cells. 